\title{
PERMEABLE MEMORIES. FAMILY HISTORY AND THE DIASPORA OF SOUTHERN NETHERLANDISH EXILES IN THE SEVENTEENTH CENTURY*
}

\author{
Johannes Müller
}

When John La Motte died in London in 1655 he was widely known and celebrated as an exemplary Christian, whose life bore such a powerful testimony to his piety and godliness that the Puritan author Samuel Clarke included La Motte's biography in his work on 'The lives of sundry eminent persons in this later age'. ${ }^{1}$ La Motte had served the city of London as an alderman and the local Dutch Reformed Stranger Church as an elder and deacon. In this function he had organised relief funds for persecuted Calvinists in Bohemia and Piedmont and made vigorous efforts on behalf of his afflicted coreligionists on the continent. A crucial element in the hagiographical accounts of his life was his own heritage of religious exile and persecution: La Motte was born in Colchester to Flemish parents who had left their hometown of Ypres for England during the persecution under the duke of Alba in the late 156os. According to his biographers, it was due to his parents' uncompromising allegiance to their Reformed faith that their son grew up as a devout and pious man who did not ignore the fate of his persecuted coreligionists abroad. In his funeral sermon, preached by Fulk Bellers, La Motte was even compared to the patriarch Abraham who had left his homeland of Chaldea to seek the land God had promised him. But even during his lifetime La Motte seems to have compared himself with Biblical exiled heroes as Moses and Abraham: on occasions like the Accession Day of Elizabeth I or his own birthday he used to invite friends to meet at his home and as

he would often say, he had desired their company, to eat bread with him before the Lord (as Jethro and Moses did) in remembrance of such and such signal mercies and deliverances, whereof his memory was a living chronicle,

\footnotetext{
* Research for this article was funded by an NWO VICI grant for the research project Tales of the Revolt. Memory, oblivion and identity in the Low Countries, 1566-1700.

1 Samuel Clarke, The lives of sundry eminent persons in this later age (London, 1683) part 2, 102 .
} 
especially those grand deliverances, both before and since the Reformation, from under the great sufferings and bloody persecutions in France, and the Low Countries, whereof he would often discourse in so punctual and feeling a manner, as if he had been an eye-witness, yea a sharer in them, taking many arguments thence of encouraging both himself and others, to be still mindfull of them in bonds and miseries, as being themselves in the body: saying, why, their case might have been ours, or may be yet, who knows? [Beller's italics] ${ }^{2}$

The remembrance of his forefathers who had left Flanders for England evidently played a central role at these commemorative meetings. Obviously, La Motte, though born in England and participating in the local politics of London as an alderman of the city, strongly identified with his parents' exile. His sense of belonging to a diaspora of Reformed refugees all over Europe seems to have been a cornerstone of his religious identity and personal devotion. ${ }^{3}$

According to Peter Ole Grell, people like La Motte belonged to the last generation of the international Calvinist diaspora. In the next generation, Grell argues, the bond with the exile heritage of their forefathers became diluted and individuals began to conceive of themselves primarily as Dutch, German or English rather than as exiled strangers in a foreign land. Grell's observation seems to be accurate in general: the children of La Motte and his contemporaries did indeed marry into English, German or Dutch families and became absorbed in the host societies of their

2 Fulk Bellers, Abrahams Interment, or, The good old-mans buriall in a good old age. Opened in a sermon at Bartholomews exchange, July 24, 1655, at the funerall of the worshipfull John Lamotte, Esq., sometimes alderman of the city of London (London, 1656), f. F4ff.

${ }^{3}$ On the Netherlandish diaspora during the Dutch Revolt see for example: Heinz Schilling, Niederländische Exulanten im 16. Jahrhundert. Ihre Stellung im Sozialgefüge und im religiösen Leben deutscher und englischer Städte (Gütersloh: Gütersloher Verlagshaus, 1972); Heinz Schilling,'Die frühneuzeitliche Konfessionsmigration', in Klaus J. Bade (ed.), Migration in der europäischen Geschichte seit dem späten Mittelalter (Osnabrück: IMIS, 2002), 67-89; M. Backhouse, The Flemish and Walloon communities at Sandwich during the reign of Elizabeth I, 1561-1603 (Brussels: Koninklijke Academie voor Wetenschappen, Letteren en Schone Kunsten van België, 1995); A. Dünnwald, Konfessionsstreit und Verfassungskonflikt. Die Aufnahme der Niederländischen Flüchtlinge im Herzogtum Kleve 1566-1585 (Bielefeld: Verlag für Regionalgeschichte, 1998); Raingard Esser, Niederländische Exulanten im England des 16. und frühen 17. Jahrhunderts (Berlin: Duncker \& Humblot, 1996); J.C.A. Briels, Zuid-Nederlanders in de Republiek 1572-1630. Een demografische en cultuurhistorische studie (Sint-Niklaas: Danthe, 1985); Peter Ole Grell, Calvinist exiles in Tudor and Stuart England (Aldershot: Scolar, 1996); Andrew Pettegree, Emden and the Dutch revolt: exile and the development of Reformed Protestantism (Oxford: Oxford University Press, 1992); Andrew Spicer, The French-speaking Reformed community and their church in Southampton, 1567c.1620 (London: Huguenot Society of Great Britain and Ireland, 1997). 
parents. ${ }^{4}$ However, as I will show in this chapter, even among these later generations memories of exile continued to be preserved and transmitted, not only in the various stranger churches but also, and perhaps more prominently so, in family circles. Intermarrying with locals and participating in the social and political life of their new host societies did not prevent migrants and their descendants from continuing to appropriate and refashion the diasporic identities of their forefathers. The exile memories of subsequent generations of migrants were, of course, not the same as those of their forebears and had to be translated into the specific context of each new generation and its living conditions in a changing society. In genealogical accounts, letters and other sources, the children and grandchildren had to reinvent and reinterpret the past of their ancestors on their own terms. As I will demonstrate on the basis of a selection of family histories of migrant families from the Southern Netherlands, the same accounts were often rewritten generation after generation. By comparing the various hands and examining crossed-out passages in the text, I was able to attribute the various changes to specific family members from later generations. As these additions and modifications of the chronicles show, the exile narrative was often blended with discourses that were shared with the native societies in which the migrants lived.

\section{Beyond the 'Memory Ghetto'}

Many studies on memory cultures among migrants, displaced groups and individuals argue that such people develop exclusive discourses about their past, which are clearly distinguishable from the memory cultures of their host societies. In many cases, migrant communities even form isolated 'memory ghettos', into which their members seclude themselves. ${ }^{5}$ These exclusive memory cultures set them apart from the rest of society and cannot easily be shared with people outside one's own minority group. In many cases, the discourses in which images of the past are

4 Ole Peter Grell, Brethren in Christ. A Calvinist network in reformation Europe (Cambridge: Cambridge University Press, 2011) 307.

5 See e.g.: Andreas Kitzmann, 'Frames of memory. WWII German expellees in Canada', in Julia Creet and Andreas Kitzmann (eds.), Memory and migration. Multidisciplinary approaches to memory studies (Toronto: University of Toronto Press, 2011), 93-119; Lauren Guyot, 'Locked in a memory ghetto. A case study of a Kurdish community in France', in Creet and Kitzmann (eds.), Memory and migration, $135^{-155}$. 
articulated within a migrant community prove incompatible with the collective memories of their host society and its imagination of the past. In such cases, the distinctive migrant identity is reproduced and marks a clear difference between migrants' own imagined community and that of their neighbors without a migration background.

Without denying the existence of such memory ghettos, this chapter will argue that it would be a mistake to consider them typical of migrant experiences of the past. In early modern Europe, at least, we can find alternatives. I will show that the numerous Southern Netherlandish refugees who left their homelands during the second half of the sixteenth century to escape religious persecution as well as military devastation did not live in such isolated memory ghettos at all. Even though they developed extremely vivid memory cultures and preserved their identity as religious exiles for centuries, the discourses in which their memories were articulated and transmitted were never totally separated from the memory canons of their host societies. On the contrary, exile memories and identities incorporated collectively shared narratives about the past of the inhabitants of their new hometowns. For people belonging to the international diaspora of Reformed migrants from the Southern Netherlands, their diasporic identity was not an all-encompassing narrative but rather one that could coexist and be combined with memories of the various host societies in which they found themselves. In many cases, migrants could even benefit from the fashioning of a distinctive exile identity: as the case of John La Motte shows, remembering the history of confessional persecution was not an issue that divided migrants and native Protestants but rather one that united them in their collective identification with the same religious cause. The commemorative meetings organised by La Motte were frequented by English Puritans as well the descendants of Flemish refugees, and it is no coincidence that they were held on the Accession day of Queen Elizabeth I, who was already celebrated as a champion of Protestantism and had long been commemorated as a loyal host by Netherlandish exiles. ${ }^{6}$

The assumption that migrants and their descendants develop and limit themselves to exclusive identities that separate them from other groups in

6 See e.g.: Simeon Ruytinck, 'Gheschiedenissen ende handelingen die voornemelick aengaen de Nederduytsche natie ende gemeynten, wonende in Engelant ende int bysonder tot Londen, vergadert door Symeon Ruytinck, Caesar Calandrinus ende Aemilius van Culenborgh, dienaren des Godlicken Woords', in J.J. van Toorenenbergen (ed.), Werken der Marnix-vereeniging, 3d series, nr. 1. (Utrecht: Marnix-Vereniging, 1873), 162. 
society has often led to the assumption that they have only two options to choose from: either they preserve their own identities and former national allegiances, or they assimilate and loosen their ties with the 'Old Country'. This notion has been criticised by scholars like Matthew Frye Jacobson, Michael Peter Smith and Nina Glick Schiller, who argue that migrant identities should not be understood in terms of assimilation and integration, on the one hand, and the preservation of old identities, on the other. ${ }^{7}$ Rather, the experience of migration should be described as producing a 'multiple emplacement or situatedness both here and there', as Michael Peter Smith has put it. Instead of belonging only to the migrant diaspora or the local society they live in, the migrants experience a 'cultural bifocality', which connects the country of origin with the new homeland. ${ }^{8}$ While studies on early modern refugees from the Netherlands have sought to determine at which point individuals ceased to identify themselves with their exile past and started to see themselves as German, English or Dutch, I suggest a change of focus; I will ask how exile identities and memories of flight and persecution were translated into German, Dutch and English contexts. ${ }^{9}$ As the following cases show, neither political participation in the new society nor intermarrying with locals put an end to the memory cultures of the migrants. While being fully 'assimilated', the descendants of Flemish refugees continued to refer to their forefathers' past until the eighteenth century or even later. Paradoxically, in many cases it was the very exile-narrative itself that allowed for participation and integration in local social systems and networks. When migrants were successful in claiming to have suffered much for the 'True Faith', they could use such claims to gain a higher social status among their coreligionists in their new hometowns, as the following examples will show.

7 Matthew Frye Jacobson, Special sorrows. The diasporic imagination of Irish, Polish and Jewish immigrants to the United States (Berkeley and Los Angeles: University of California Press, 2002); Nina Glick Schiller, Linda Basch and Cristina Szanton Blanc, 'From immigrant to transmigrant. Theorizing transnational migration', Anthropological Quarterly 68 (1995), 48-63; Michael Peter Smith, Transnational urbanism. Localizing globalization (Malden, MA: Wiley-Blackwell, 2001).

8 Michael Peter Smith, 'Translocality: A critical reflection', in Katherine Brickell and Ayona Datta (eds.), Translocal geographies. Spaces, places, connections (Burlington: Ashgate Publishers, 2011) 181; Michael Peter Smith, 'Can you imagine? Transnational migration and the globalization of grassroot politics', Social Text 39 (1994), 15-33, there 17, 18.

9 Grell, Brethren in Christ, 307; Grell, 'The creation of a transnational, Calvinist network and its significance for Calvinist identity and interaction in early modern Europe', European Review of History 16 (2009), 619-636. 
All the families studied in this chapter belonged to the higher social strata and some even to the economic elite of their host societies. As has been argued by scholars on early modern migration in the Netherlands, the social integration of Southern Netherlandish migrants in the Dutch Republic started in the lower social strata, while migrants from the elite stayed relatively long within their own circles and intermarried with fellow southerners. Niek $\mathrm{Al}$ and Clé Lesger even postulated a process of 'integration from below'. ${ }^{10}$ Though there is much evidence that endogamy was practiced longer in the migrant elite circles than in the lower strata in society, I will argue that the rich and well-educated families were no less integrated because they married within their own group for a longer period. In fact, the relationship between the practice of endogamy and the preservation of the feeling of belonging to the diaspora is far from straightforward. As the following cases suggest, the practice of ex- or endogamy may actually not be such a good indicator of the degree of identification with the new host society or the lost homelands.

\section{Reinventing Family History}

Many of the refugees who had left the Southern Netherlands during the early revolt against the Habsburg government in the 1560 s and 70 s and after the capitulation of the important rebel towns of Antwerp, Ghent and Brussels between 1580 and 1585 saw their exile as only a transitory period after which they would be able to return home. Many roamed through the German Protestant territories, the Northern Netherlandish Provinces and Britain and were hopeful that the military campaigns under Stadholder Maurice of Orange would lead to the eventual downfall of Habsburg rule in the south. Family letters of southern migrants from the late sixteenth century are full of expressions of nostalgia and homesickness. Antwerp merchant Johan Thijs, who had fled Antwerp for Holland, frequently wrote to his brother-in-law Andreas de Bacher that he longed for a reunion of the family in what he called 'the Promised Land'. ${ }^{11}$ Until the first years of the seventeenth century he remained full of hope for a future in the

\footnotetext{
10 Niek Al and Clé Lesger, 'Twee volken besloten binnen Amstels wallen'? Antwerpse migranten in Amsterdam omstreeks 1590', Tijdschrift voor Sociale Geschiedenis 21 (1995), 129-144, there 140 .

11 Archief vande familie Thysius, Leiden University Library (Arch. Thys.), 133: C3: Brieven aan Andreas de Bacher. January 26, 1606.
} 
fatherland. In 1599, he reasoned that the Spanish enemies had pushed their luck too far and that defeat was at hand, which would enable his family to return:

Our hope is, that the war, which has endured for so long now, will soon be over and that at last we can return to Antwerp, the city of our fathers. Because the haughtiness of the Spaniard has already reached its climax and it seems, that he who has afflicted all the world, is afflicted himself and that he has suffered harm and mockery, not only at Schenckenschans, but also in Nijmegen. ${ }^{12}$

When the military campaigns of the Republic failed to recapture the Southern Habsburg territories in the first years of the seventeenth century, it occurred to Thijs that exile was not a temporary situation and that his future now lay in Holland. By early 16o6, he had lost hope:

But now I am in doubt and I start to question the (possibility of a coming) peace. Therefore I have resolved to buy a house here and to forget Antwerp. ${ }^{13}$

While in the previous years Thijs' correspondence with his relatives had been full of references to a future in Antwerp and his longing to return, this letter seems to mark a definite end to his hopes. From 1606 onwards his writings are devoid of any mentions of the past. Many fellow-exiles of his generation seem to have fallen into silence about their past and often tried to forget it.

In many cases, it was only in the next generations that individual family members tried to reconstruct their family history and attempted to preserve what they could of the exile past of their forefathers. We can, for example, observe this phenomenon in the case of the Van der Muelen family. In the late seventeenth century, Willem van der Muelen, greatgrandson of former Antwerp alderman Andries van der Meulen, who had left his hometown for Holland, recorded what he could remember of family stories. He also eagerly collected material evidence of his ancestor's refugee past, such as a letter of recommendation by the rebel government of Antwerp, to which he added that his great-grandfather had always behaved as a good patrician and remained loyal to the cause, which forced him to leave his hometown. ${ }^{14}$

12 Arch. Thys. 133: B1: Brieven aan Andreas de Bacher. July 13, 1599. All translations into English are by the author.

13 Arch. Thys. 133: B2: Brieven aan Andreas de Bacher. April 20, 1601.

14 Het Utrechts Archief, 57, inv. nr. 27; 59. 
The family's engagement with its own past had first become manifest in the second generation after the migration to the Dutch Republic: Andries van der Muelen the Younger, Willem's grandfather, was deeply concerned with proving that the Van der Muelens were descendants of a Southern-Netherlandish nobleman who had served the King of France in the eleventh century. In the 1640's he corresponded frequently with his relatives to gather more information about the assumed noble descent of his family and even changed his name from Van der Meulen to Van der Muelen, when his genealogical studies seemed to suggest that this spelling would be more correct. ${ }^{15}$ In addition to this assumed connection to a noble family it was the family's fate of having fled the south for the sake of the Reformed faith that interested him. In $165^{\circ}$ he asked Nicolas de Malapert, a friend of his parents from their time in Antwerp, to sign an affidavit that his parents had left Antwerp in 1585, immediately after the siege of Parma, although the city's Protestant inhabitants had been granted a four-year grace period in which to settle their affairs before the mandatory obligation to convert to Catholicism went into force. By doing so, he could prove that they had been uncompromising Protestants, unwilling to live under the new Habsburg Catholic regime. He also wrote down the story of his uncle Jan van der Meulen who had lost his life defending his hometown during the 'Spanish Fury', a devastating mutiny of Habsburg soldiers in $1576 .{ }^{16}$

In the case the Martens family, also from Antwerp, the same pattern is recognisable. Within the circle of this family a wide range of sources was transmitted to future generations in which the family history was not only preserved but also frequently rewritten. I have studied about ten different manuscripts that heavily borrow from each other, and by comparing handwritings and textual structures I was able to reconstruct how the family memories in the Martens family evolved over time and how the history of the family was rewritten by the various generations.

Very much like Andries van der Meulen the Elder and Johan Thijs, Hans Martens did not leave much information about his flight from the south, although later sources suggest that he sometimes talked to his children about their family's past. ${ }^{17}$ The only notes he left were in tabular form and concerned the births of his children, his marriage and business. Hans' son,

\footnotetext{
15 Ibid., inv. nr. $5^{8 .}$

16 Ibid., inv. nr. 3 .

17 Het Utrechts Archief, 1002, inv. nr. 1.1.
} 
Carel Martens, was an ambitious youth, who was so eager to enter the elite networks of Holland and Utrecht that he went to the Synod of Holland as a seventeen-year-old and asked everyone he thought important enough to write in his album amicorum. ${ }^{18}$ We can find Francis Gomarus, Gisbert Voetius and other famous Counter-Remonstrant theologians in the book but also various members of the Nassau family and poets and scholars like Daniel Heinsius. Carel not only copied his father's autobiographical notes but added a more detailed biographical description and tried to find out as much as he could about his family's past. ${ }^{19}$ In 1633 , he invited his uncle Jacques Martens to Utrecht to confer with his half-brother Hans and to write down everything they recalled about their ancestors. When his son Jacob married Aletta Pater, a girl from a highly influential Utrecht family, Carel and his wife Jacoba Lampsins, also from a rich southern family, commissioned four paintings by Ferdinand Bol, which, according to art historian Margriet van Eikema-Hommes, symbolically represented the entrance of an exiled family into the established elite of Utrecht. ${ }^{20}$ All the four paintings showed well-known Biblical and classical foreigners and exiles, such as Aeneas, Moses, Abraham and the people of Israel in Babylonian captivity. In the paintings the depicted exiles are presented as victors, who despite the hardships of exile had been successful in creating a new genealogy. Like Aeneas, the Martens and Lampsins families had founded a New Troy, and like Abraham and Moses they were bound for the 'promised land' and fathered a new generation of godly people. Just as with the La Mottes in England, the dissemination of the exile narrative could improve their status among the elite circles of Reformed orthodoxy. ${ }^{21}$

Jacob, Hans Martens' grandson, put his family's history into a more structured narrative form and wrote it down in a 'memorie boeck' of which there are numerous copies extant. ${ }^{22} \mathrm{Jacob}$ took the notes of his father and grandfather and complemented them with things he knew from family stories, such as the exact places where his great-grandparents in Antwerp were buried. The actual narrative 'plot' begins with the migration of Hans and his siblings in the period of the very early Revolt:

18 Ibid., inv. nr. 40.

19 Ibid., inv. nr. 60.

20 Margriet van Eikema Hommes, Art and allegiance in the Dutch Golden Age. The ambitions of a wealthy widow in a painted chamber by Ferdinand Bol (Amsterdam: Amsterdam University Press, 2012), 151ff.

21 Ibid., 165.

22 Het Utrechts Archief, 1002 inv. nr. 1.1-4. 
The children of Francoys Martens fled to Amsterdam for religion's sake under the Spanish persecution and were separated from each other during the reign of the Princess of Parma as well as the persecution of the duke of Alba $[\ldots] .^{23}$

Even though Hans Martens' considerably older brothers were already young adults in the time of Margaret of Parma, Hans himself was born in 1555 and only twelve years old when Margaret resigned and was replaced by the duke of Alba. His notes show that Jacob was in doubt about the date when his grandfather had left Antwerp:

Hans Martens fled Antwerp for religion's sake during the troubles under the duke of Alba in the year... [lacuna] and left for Amsterdam with some of his brothers and sisters, where he settled down in silence as a merchant. Through the persecutions he had become a devout and godly man, who did not care about the grandeur of the world and and because he wanted to avoid prestige, he refused to use his family's coat of arms [...]. ${ }^{24}$

The lacuna in the text about the year of Hans Martens' flight from Antwerp can be found in all existing manuscripts. Obviously, the regimes of Margaret of Parma and Alba were so central to the collective memory of Dutch Protestantism that in the oral tradition things became mixed up. It is, however, rather unlikely that the young teenager Hans had indeed left his hometown as early as the 1560 s when his parents still lived in Antwerp. The first records of his existence in Amsterdam date from the early 1580s, a time when Antwerp was still in rebel hands.

At the time of Jacob's marriage the Martens family had already entered the Reformed elite of Utrecht, and the story of the grandfather, who 'did not care about the grandeur and the haughtiness of the world' and had become a 'devout and godly man' in and through exile fitted well into the circles of orthodox Reformed Utrecht in the era of Gisbert Voetius, the leading light of the 'Further Reformation' movement. Nevertheless this narrative also had a problematic aspect. The earliest versions of the manuscripts read:

[Hans Martens] has always said to his children that he descended from the best and finest families of Antwerp, but that he had learned through the persecution to hold in disdain the grandeur of old families and to keep himself quiet and humble and therefore refused to use his coat of arms which could be found everywhere among his popish family in Antwerp. ${ }^{25}$

23 Ibid., 1002, inv. nr. 1.2.

24 Ibid., inv. nr. 2.

25 Ibid. 
At the time when the story was written down, the Martens family were themselves acting like an 'old family' and had become conscious of their family and dynastic identity. And, of course, Jacob himself already realised the inconsistency of this narrative. In later manuscripts he changed the text and crossed out all the passages about Hans' contempt 'for old and famous families'. The phrase 'He had learned through the persecution to hold in disdain the grandeur of old families' was from then on erased and replaced with: '[...] the persecutions taught him to forget his ancestry.'26

While families like the La Mottes in England and the Martens family in the Dutch Republic represented their past in terms of godliness and confessional steadfastness when entering Puritan and orthodox Reformed networks, others deployed discourses of patriotism and national consciousness to establish their position in their host societies. The members of the wealthy Panhuys family, whose forefathers had also fled Antwerp, not only invented a noble lineage for their ancestors but also strongly emphasised the notion of their common Netherlandish ancestry that united them with their neighbours. While most of their ancestors originally came from Limburg and the region around Trier and Liège, they had established themselves in the elite merchant circles of Antwerp during the sixteenth century. In their family chronicle they introduced the history of their bloodline with an account about the ancient Batavians who were praised by Tacitus and from whom the Netherlanders descended. ${ }^{27}$ The Batavian past was a popular motive in the historical discourse in seventeenth-century Holland, though the actual geographical origin of the Batavians was disputed by the various provinces of the Netherlands, which claimed to be descendants of this legendary Germanic tribe. These disputes are not mentioned in the Panhuys chronicle and a common Netherlandish origin is evoked: the ancient Low Countries are portrayed as stretching from the Meuse region to Northern France and even the French noble house of Capet is included into the list of old Netherlandish noble families. By appealing to the patriotic feelings of the inhabitants of the Dutch Republic, the Panhuys family tried to evoke a connection between themselves as migrants and the elites in their new hometowns Amsterdam and Utrecht. Even though their claims of descending from nobles were often disputed during the seventeenth century, they were able to enter the elite circles of the Dutch Republic. For centuries, the

26 Ibid., inv. nr. 1.3; 1.4 .

27 Regionaal Archief Leiden, LB 6331, Cort verhael van het out ende adelijck geslachte van Panhuijs, afcomstich uut den lande ende vorstendom van Limburg, 1270-1817, f. 5r. 
emphasis on their Netherlandishness and their 'natural' bonds with their neighbours in the North remained a crucial element of the tale the family told about its own history. When the family was at last officially admitted to the nobility in the new Kingdom of the Netherlands in the nineteenth century, the family chronicles were extended and the Panhuyses presented as an old and well-established Dutch family. ${ }^{28}$

\section{Permeable Memories}

The cases of the family histories of the Martenses, the Van der Muelens and many other southern families in the Republic show how memories were preserved long after the time that their descendants had married into local families and had begun to participate in local politics and cultural life. While exile narratives had initially emphasised the migrants' status as strangers who hoped for a return to their homeland, from the second generation onwards their character and function changed: instead of stressing the differences between strangers and locals, the memory of an exile past could help the children of the refugees to build ties with the networks of the local host societies. Stories of exile and suffering served as a narrative of origin that legitimised the status of the migrant families as homines novi. The mists which had settled over some family origins before the time of migration could be seized upon to claim a higher social status: since the family was not known in the host society, stories about noble descent could hardly be disproved. At the same time the assertion that the ancestors had been so godly and pious that they had avoided any identification with their popish relatives and therefore denied their ancestry could be also be appealing to the religious elites of their new homes.

Instead of forming exclusive 'memory ghettos', migrant families such as these therefore developed memory cultures that did not separate them from the discourses and narratives of their host societies but in fact proved highly permeable. Migrant families easily combined their own exile narratives with religious and political discourses of their host societies, such as the hospitality towards their ancestors under Queen Elizabeth and her restoration of Protestantism in England or the narrative of the struggle against the Spanish oppressors in the Dutch Republic. The imagined diaspora of the numerous refugee families from the Southern Netherlands

28 Ibid. 
should therefore not be understood as a dividing line between locals and strangers. It was not despite, but rather because of, the commemoration of their immigrant background that these families were able to enter local networks and attain a higher social status in their host society. Becoming Dutch, English or German did not imply oblivion of the diaspora past and the identification with the local society could perfectly be combined with the cultivation and reinvention of the exile narrative and identity.

These findings also carry some important methodological implications. While migrant diasporas are often understood as producing an exclusive form of identification with their own group, endogamy and the transmission of traditions and memories are often used as the most important indicators of the degree to which the diaspora is still extant. ${ }^{29}$ However, as I hope to have shown, the notion of a transnational diaspora does not have to be diminished by the strengthening ties of the individual migrants with their host societies. In migration studies, a diaspora should therefore not be conceived of as something which is extractable from a given set of data on marriage patterns or social and economic behavior but rather as a horizon of belonging and identification which may be expressed only occasionally and which does not have to conflict with the loyalties migrants feel towards the communities where they reside. As the cases of the La Motte, Martens or Van der Meulen families show, the opposite development could also occur: remembering exile strengthened their feeling of belonging to their host society. Being Protestant, being English or Dutch and descending from an exiled family were identities so closely welded together that they were sometimes no longer detachable from each other.

29 See e.g.: Al and Lesger, 'Twee volken besloten binnen Amstels wallen'?; Gerard van Gurp, 'Bosschenaars in de verstrooiing. Emigratie tussen 1579 en 1629', Tijdschrift voor Sociale Geschiedenis 23, nr. 4 (1997), 401-427, there 420ff.; Leo Adriaenssen, 'De brabantisering van Haarlem in 1579-1609', Noordbrabants historisch Jaarboek, 24 (2007), 102-135, there $120 f f$. 